\title{
East of the West: Repossessing the Past in India
}

\author{
INDIRA CHOWDHURY AND SRIJAN MANDAL
}

$\mathrm{A}$ lmost nothing that would be recognised as public history elsewhere is identified as such in India. Despite its long and ever-increasing acceptance outside India as a discipline and a practice distinct from traditional academic history, it has yet to gain acceptance in India. Attempts to identify Indian activities, practices and outcomes - such as books, films, archival collections and exhibitions that are self-consciously public history will not yield much fruit. Nor, necessarily, will trying to apply any of the many Western definitions of the term in the Indian context. Instead, this article will try to highlight the myriad forms that public engagements with the past have taken in India. It focuses specifically on museums, arguably the preeminent site

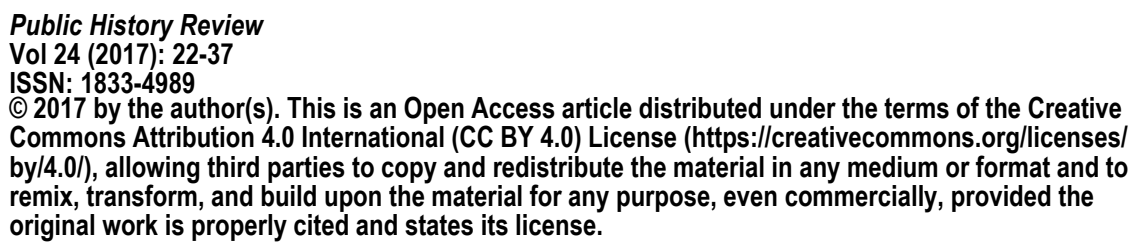


of public engagements with the past in the country. To that end, we will look at a new generation of museums that are forging fresh pathways to enable better public engagement with the past. It will also analyse a few institutional forms of public engagement with the past.

In India, there exist practices that actively engage with the past. Sometimes these are seen as resources that historians might use. But more often they are viewed as resources that belong not to history but to anthropology and folklore. This may have to do with the mechanisms that established history as an academic discipline in India. However, practices that engage actively with the past and use songs, performances and puppetry continue. The records kept at pilgrimage sites or genealogical tables preserved in memory by communities such as the Manganiyar in Rajasthan are consulted by people to understand family history.

The tradition of the Kavaad, or wooden story-telling box that opens out to reveal the story, very often incorporates genealogy. There have been a few attempts in recent years through film to engage with and document these practices in order to understand these kinds of public engagement with the past. Filmmaker Nina Sabnani has used indigenous aesthetics and forms of story-telling to depict a community's engagement with the Partition and the wars between India and Pakistan in her 2009 animated film The Stitches Speak. ${ }^{2}$ Sabnani's attempts to bring together older traditions of engagements with the past with new ways of presenting it have not been engaged with by historians except as resources or sources of information. But even these resources are often ignored by mainstream university departments as not being proper resources for academic history which was introduced during the colonial period.

History - that is, the academic discipline that we research, teach, and study in universities... that was invented in Western Europe in the early part of the nineteenth century ${ }^{\prime 3}$ - did not become a subject of postgraduate study until 1919, when the University of Calcutta established a department for the study of medieval and modern history. Other universities followed suit over the next two decades. ${ }^{4}$ This means that until about a century ago, there were no Indian historians formally trained in the subject, at least not in a university. Yet, by the time history became a subject of postgraduate study, it had already been around and flourishing for a few decades as history had developed in the public sphere at the hands of amateurs amid a public 'hunger for history', a phrase that the celebrated Indian author Rabindranath Tagore used in 1899 to describe his times. ${ }^{5}$ 
These amateurs debated the ways that the past can be studied in a 'scientific' manner, an approach that had become available to them through the agency of colonialism and the colonial attempts at 'scientifically' studying the pre-colonial Indian past. However, they were not satisfied to merely study the past scientifically. As one of them put it, they also wanted to promote it 'among ordinary people in accordance with scientific methods'. Otherwise, history would be little more than 'mere argumentation among the learned'; 'they thought of the historian as a custodian of the nation's or the people's memories.' ${ }^{\prime}$ This conception of the historian as custodian has continued to this day. Accordingly, the public role that historians have sought for themselves is that of adjudicating 'disputes relating to the past arise in the domain of popular culture'. ${ }^{.}$However, this role has not been offered to them by the public. Most attempts by historians to assume this role for themselves has made little difference in the outcome of public disputes about the past. Despite that, historians continue to try to find a role for themselves in the wars over history that engulf the country from time to time.

\section{Publics AND THEIR PASTS}

Public history in India, to the extent that it involves historians trying to adjudicate public disputes about the past, is as old as the discipline of history itself. However, public history understood thus came into prominence in 1990 when the faculty of the Centre for Historical Studies at the Jawaharlal Nehru University in New Delhi published a pamphlet refuting the claims that were being made about the Babri Masjid-Ram Janmabhumi dispute over the site of Rama's birthplace. ${ }^{\mathrm{s}}$ The pamphlet presented historical evidence to refute communal beliefs that were being treated as history and used in the perpetuation of communal politics. The next year, an edited volume that expanded upon the pamphlet and provided contextual depth to it was published. ${ }^{\circ}$ While this unprecedented intervention did garner some attention, it failed to affect public perception of the Babri Masjid, which was ultimately torn down by hundreds of kar sevaks - Sangh Parivar activists - on 6 December 1992.

Among the historians, Romila Thapar was the most prominent voice to emerge in this conflict. This was not the first time Thapar had found herself fighting against the political abuse of history in the public sphere. In the late 1970s, she and her colleagues, both at the Centre for Historical Studies and elsewhere, had to defend textbooks they had written for the National Council of Educational Research and Training in the 1960s. The same Sangh Parivar had taken exception to the interpretation of history contained in them and, with the then Prime Minister Morarji Desai's 
blessing, sought to stop the books being used.10 The battle over textbooks was reignited in the early years of this century when the Sangh Parivar was back in power through its political wing, the Bharatiya Janata Party. Yet again, Thapar and her colleagues had to defend the discipline of history from the political distortions that were sought to be imposed upon it." In other words, Thapar has been playing the role of a public historian for more half a century now without ever identifying herself as such.

Thapar's and others' attempts to adjudicate public disputes about the past or promote historical method have recently met with resistance from an altogether different quarter: the Dalit-Bahujan samaj- society of the oppressed and the majority. For them, 'the past has been an integral and constitutive element of identity assertion and also a medium for coping with the oppressive present. '12 The discipline of history, they claim, is not equipped to do that and public history derived from this conception of the discipline is irrelevant to such an enterprise. Here, they seek to create an 'alternative history', 'as a form of dissent' through 'the use of dissenting cultural resources like myths, legends, local heroes and histories. '1 ${ }^{\prime 3}$ The purpose of such a history is Dalit - oppressed castes mobilisation for political power that is sought to be achieved through raising Dalit consciousness."

Whether it is the caste Hindu public or the Dalit-Bahujan public, the past serves a political purpose in the present and, as such, must be projected in a manner that serves that public's stated political purpose. For such a task neither the discipline of history nor the public role of adjudicator that a professional historian may want to assume is equal, which is why historians tend to be so marginal in public contestations about the past.

\section{COLONIAL CURIOSITIES AND the POSTCOLonial Museum}

Museums present one way of engaging the public with the past. Calcutta, the first capital of British India, was home to Asia's first museum. The Museum of the Asiatic Society began in 1814 and had a very diverse collection. As in other colonies, museums in India were seen as part of civilising machinery through which colonial subjects could understand and access their past through a scientific lens. The museum, one of the earliest tools of public history, had a slightly different educational agenda in the colonies. Through the objects on display, colonial subjects, who occupied a lower position on the evolutionary ladder, could view their own glorious past which contrasted sharply with their worn-out and depleted present. ${ }^{15}$ 
The early history of the museum shows how the collection of archaeological, botanical and zoological objects was organically linked to expeditions undertaken, wars fought and excavations conducted. The museum soon expanded and became what we now know as the Indian Museum in Kolkata. It also moved in 1878 to its present premises, an imposing neoclassical building designed by Walter Granville. If the colonial state saw museums as places to display the geographical boundaries of the empire, the coming of Indian Independence in 1947 brought with it new dilemmas. The Indian Museum became one of the sites where 'the drama of decolonisation was played out with all its contradictions and paradoxes. ${ }^{\prime 1}$ Since Indian Independence came with the Partition of British India into India and Pakistan, old artefacts and objects of historical significance were redistributed between the two countries.

During 1947 and 1948, an exhibition of Indian Art with selections from museum artefacts as well as works by contemporary artists was put up in Burlington House, London, as part of the Royal Academy Exhibition of Indian Art. When the artefacts returned to India, they were displayed at the Raj Bhavan - the official residence of the President of India, which until 1947 was the viceregal palace. This exhibition was not very successful in London but it was 'destined to have a far more significant afterlife in Delhi' as the artefacts borrowed from various museums went on to form the core collection of what came to be the

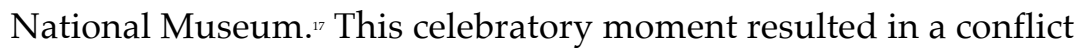
between the older Indian Museum and the newly put together National Museum. The Indian Museum refused to part with some of its artefacts. The oldest and the largest museum in India was not identified as the National Museum but recognised as an institution of national importance. The creation of the National Museum in the capital became 'an act of great symbolic importance after independence', and the new museum was seen as celebrating the 'ancient culture of the young state.' ${ }^{\prime s}$ The creation of the new museum thus signalled the creation of a new narrative of the state. It was this narrative that was replicated in different museums and showcased especially for school children who visited regularly. Museums thus became pedagogic sites for the new citizens to understand their past and post-Independence identities.

\section{THE MeHRANGARH FoRT}

The celebratory narratives of the nation resulted in heritage sites being interpreted in uncritical and self-congratulatory ways. The numerous 
archaeological sites strewn across India became sites of pilgrimage for new citizens. The narratives, however, remained simple and shied away from presenting complicated histories. The Mehrangarh Fort in Jodhpur is a case in point. Mehrangarh, one of the largest forts in Rajasthan, houses a museum. The fort was built by Rao Jodha who ruled in the fifteenth century and named Mehrangarh - 'Fort of the Sun' - referring to the fabled descent of the rulers from the Surya - the Sun god. The fort museum showcases Rajput courtly life and has galleries that showcase elephant howdahs - the ornate carriages placed on elephants - of the maharajas, the palanquin - or litter, which was the mode of transportation for women until the early twentieth century - cradles, weapons, textiles, turbans and paintings.

The paintings and material culture reflect the relationship between the Rathores - the ruling clan of Jodhpur - and the Mughal emperors of whom the clan were important allies. In the early seventeenth century, the Rathores employed painters to prepare Mughal-style paintings. In a few decades, however, the painters developed their own distinctive style, based on earlier local traditions. This came to called the Marwar School and the museum houses the finest collection of these paintings. The narrative adopted by the audio guide uses a triumphant tone and does not provide a glimpse into the complicated history of the fort. We see the stones with hand imprints of the fifteen royal widows who committed self-immolation but we are not told about the gendered history of sati - the funeral practice where women immolated themselves on their husband's funeral pyre.

One is left wondering whether a more complex history, one that has been explored by academics, can be told at all when a site is conserved and supported by the present-day sucessors of the royal family. The head of the family still remains the custodian of the fort. With the coming of Independence, most of the former princely states integrated with India and with the abolition of the privy purses in 1971, erstwhile royal families were no longer entitled to payments and privileges from the central government. Under the new dispensation, most of them found it difficult to maintain their palaces and forts. While some handed their buildings to the government for museums, other hired out palaces to hotel chains.

Mehrangarh Fort continues to be run by the family of its former rulers. As Thomas Cauvin has reminded us, public historians would need to carefully reassess the historian's traditional role and its relations with the many actors involved in the production of historical narratives. ${ }^{19}$ The narrative adopted at the fort creates a glorious narrative for the 
consumption of tourists. The critical questions - whose heritage is being curated and how can it be represented? - can be asked in academic articles. But this may not have an impact on the grand narrative adopted at the site.

\section{ARnA-JHARNA: The DESERT MUSEUM OF RAJASTHAN}

Reflecting on public history more than three decades ago, Ronald J. Grele argued that the term calls for a redefinition of the role of the historian. For him, public history 'conjures up images of a new group of historical workers interpreting the past of heretofore ignored classes of people.' ${ }^{20}$

The Arna-Jharna, or the Desert Museum of Rajasthan is run by the Rupayan Sansthan. It adopts a similar position on the role of the historian by reimagining the museum as a space where the link between land and livelihood, cropping patterns and cultural ethos, material culture and tools can be investigated and examined by the visitors. Envisioned by Rupayan's founding director Komal Kothari, Arna-Jharna presents his idea of Rajasthan as being divided into three zones - the millet zone, the wheat zone and the sorghum zone. Each of these zones have different environments, different food items, different tools and different cultural practices. All exhibitions at the museum are arrived at through this process of focussing on the zone and understanding environment, food, material culture and traditions. As Kuldip Kothari, the present secretary of the Rupayan Sansthan, puts it:

When a culture dies, you put things in the museum to understand the past. But [here] we are talking about a living tradition - the past is already there - embedded in the present. When you look at pottery - it has existed for millions of years - it's the same process, the material is there. ${ }^{21}$

The broom project - the first project undertaken by the museum - was directed by writer, academic and cultural critic Rustom Bharucha, who had earlier published Rajasthan: An Oral History based on extensive interviews with Komal Kothari. The broom exhibition focuses on the environment and natural resources, modes of production, lives of the broom-makers who belong to marginalised caste groups, myths, beliefs, symbolic dimensions of the broom and the broom economy.2 The collection of 350 brooms is classified according to use and place of origin. Arna-Jharna engages its audiences through community involvement broom-makers are invited whenever children visit, while conversations with rural visitors about the broom often results in the collection being 
enhanced. As Rustom Bharucha has said, through the humble broom the museum is able to focus on unheard histories: 'Our social function as a museum is in terms of making the inaudible audible; making the invisible visible... we are serious about calling attention to their practice and predicament. ${ }^{\prime 23}$

\section{VIRASAT-E-KHALSA}

The idea of living history - of presenting traditions that originate in the past but are still practised - creates a dilemma about representation. The Virasat-e-Khalsa, a museum of Sikh heritage, presented a similar challenge to designer Amardeep Behl. The museum was initiated by the Government of Punjab in 1999 to commemorate 300 years of the birth of the Khalsa tradition, a critical event in Sikhism. The renowned architect Moshe Safdie was commissioned to design the building. Inspired by the landscape and other historic sites in the area, Safdie created a grand edifice using earth, water and sky elements. While the building was unusual, it had been designed before the inner life of the museum could be conceptualised.

When Amardeep Behl was invited to conceptualise the museum, he was convinced that a living tradition had to be communicated through narratives. And yet, if the historical timeline had to be traced from Guru Nanak, the founder of Sikhism, to the tragedy of India's Partition which resulted in death and forced migration of the Sikhs - it could not be traced as a linear progression. For one, if the audience had to enter the ground floor to see the early history of Sikhism and exit from the top floor, where they would witness the catastrophe of 1947; it would mean that violence and carnage would be placed quite literally above the heads Sikh Gurus who would be there on the ground floor. ${ }^{24}$ For Behl, such an arrangement would not only be disrespectful; it would also go against the spirit of what the museum stood for.

In consultation with the architect, Behl devised a way in which the audience enters through one wing and walks up a ramp witnessing a dynamic narrative panorama which introduces them to the countryside of Punjab. The joyous songs that play as different parts of the panorama light up, creating an atmosphere and a mood. Only after the audience has been introduced to the land and its culture are they handed the audio guides that introduce them to the lives of the Sikh Gurus and take them through the history of the Sikhs. As the narrative progresses, the audience moves from the top floor, which tells the history of the Gurus, to the ground floor, which talks about the Partition. 
The Virasat-e-Khalsa is a narrative-based museum with music and poetry. But this is a museum without objects. The narrative pauses from time-to-time to concentrate on spectacular installations that focus the mind on key spiritual teachings of Sikhism. The stories are told through embroidered textiles, inlaid stone-work, wood carving and other crafts. Unlike other government-administered museums, the Virasat-e-Khalsa allows audiences to touch the displays, take photographs and carry on discussions about the displays.

In many ways, both Arna-Jharna and Virasat-e-Khalsa signal a new moment for public engagement with the past in India. They both challenge the notion that living traditions cannot be seen as historical sources. And above all, they foster active audience contibutions to the life of the museum.

\section{REMEMBER BHOPAL MUSEUM}

The Remember Bhopal Museum, proclaimed 'the first museum of the world's worst industrial disaster', is almost unique in the annals of public history in India. This stems from the fact that it is a 'survivor-led effort', 'collectively curated by a community of survivors and activists.' 2 In that sense, it is truly a manifestation of a people's past - a past that is not only of a people but also by those people.

Inaugurated in December 2014, on the thirtieth anniversary of the Bhopal Gas Disaster, the museum is an act of resistance - a slap in the face to the Government of Madhya Pradesh. The government has proposed building a memorial at the site of the contaminated Union Carbide factory, from where forty-two tons of the lethal methyl isocyanate (MIC) had escaped into the air on 3 December 1984, killing about fifteen to twenty thousand people and leaving half a million more exposed to its harmful effects. But the government has chosen not to formally consult the survivors of that horrific night, ${ }^{26}$ opting instead to commission, without their collective consent, SpaceMatters - a Delhibased 'integrated design practise' - to build a memorial. ${ }^{z}$ Given the government's complicity in the travesty of justice that has been meted out to survivors since the disaster, they do not believe that the government has the 'moral right' to build such a memorial, much less hire a firm to do this that has lost the trust of the survivors and activists and is deemed 'dishonest, incompetent and complicit with the state government' ${ }^{28}$ It is against this attempt to appropriate the past that the Remember Bhopal Museum exists. ${ }^{2}$

That is why the museum accepts no government or corporate funding, surviving instead through small donations from individuals 
and contributions from environmental activist groups in India and abroad. ${ }^{30}$ This has allowed the museum to retain its character as an impassioned indictment of corporate crime and state apathy and a symbol of the survivors' resilient struggle against both. Its galleries are accordingly curated to evoke in the audience's mind a range of emotions - from horror to anger to despair - all achieved through the deft use of images, voices, objects and text. Images, both well-known and littleknown, line the walls of every room of the two-storeyed museum, each accompanied by a text that explains its context and connects it to the narrative being woven through them. Alongside the images in each room is a bank of wall phones, each containing the haunting voices of those who survived and those who continue to fight.Some of these voices recount the events of that fateful night; some of how it could have been prevented. Others tell of how those responsible were allowed to go scot-free and how so many continue to fight a seemingly losing battle.

These images, voices and text come together to give meaning to the everyday objects of everyday people that are also on display in each gallery. Contextualised thus, something as commonplace as a child's clothing takes on a tragic meaning, as does the stethoscope of a doctor, all representative of the havoc that the leaked gas wreaked on the residents of Bhopal. By thus challenging the monopoly of the state in memorialising the past, the Remember Bhopal Museum has managed to not only commemorate a movement for justice, but also continue it through the four walls of a museum.

\section{THE PARTITION MUSEUM}

Half a million people killed, seventy-five thousand women violated, and ten million refugees created: these are some of the staggering, yet ultimately sanitised, statistics of the retributive genocide that followed the partition of British India. Yet, for almost seventy years after this cataclysmic event, 'no memorial, no designated space, no commemoration of any kind's had been established to mark the momentous migration that accompanied the birth of these two nations.

The Partition Museum in Amritsar was formally inaugurated on 17 August 2017, on the seventieth anniversary of the announcement of the so-called Radcliffe Award which demarcated the border between India and Pakistan. The museum seeks to present a people's view of partition. It is rooted in their memories of the event and its aftermath.

Oral history interviews play a central role in the museum. Carefully chosen excerpts from these interviews are played on LED screens with headphones attached to each screen for interested individuals to listen to 
the interview. Accompanying many of these interviews are personal objects - for instance, a letter, a suitcase, a piece of clothing - that are either referenced in the excerpts or are relevant to the person's memory of partition. As with the Remember Bhopal Museum, the Partition Museum elevates these everyday objects by endowing them with meaning found in the extraordinary experiences of those who endured partition with them. These oral history interviews do not exist in isolation. They are contextualised by the broader picture that is creatively displayed within which these individual experiences unfolded. That is why the first gallery is about the high politics of partition and the Radcliffe Award itself, a process that is depicted through key archival documents, evocative photographs, contemporary maps and oral history interviews.

Despite the traumatic events that it depicts, the museum has made a curatorial choice to not dwell on barbarities that people committed in the name of avenging their co-religionists in the aftermath of partition. Instead, it highlights acts of compassion, of courage, of even joy like a wedding; ordinary acts that became extraordinary by virtue of the circumstances in which they occurred. The feeling that the exhibits leave one with is of hope - that even in those dark times there were some who survived the ordeal with their humanity intact. In keeping with this theme, the museum ends with the tree of hope. From it hang messages from visitors of their impression of the museum. The gallery has also uplifting stories of how survivors of partition, without a penny in their pocket, became successful in this new country that they now had to call home. Through such curatorial decisions, the Partition Museum has chosen to commemorate the truth of partition while paving a path towards reconciliation.

All the museums discussed here are public engagements that are very different in scope and character from traditional Indian museums. As we have seen, after independence museums in India were created to celebrate the achievements of the new state. As Ashton and Trapeznik have pointed out, 'the nation state certainly underwrote the evolution of history with a public purpose through massive investments in cultural institutions and universities' ${ }^{33}$ State-funded museums in the Indian context have only recently began experimenting with new forms of audience engagement. While it might be argued that private museums have more freedom than those that are state-run, the unique and grandly built government-run Virasat-e-Khalsa is an exception. Perhaps the reimagined museums signal a moment of readiness for experiments with public history. 


\section{PUBLIC HISTORY INTERVENTIONS AND INDIAN ACADEMIA}

Public history interventions in India, as elsewhere, have often come from outside academia. Although there has been no local public history movement in India as such, organisations such as the Indian National Trust for Art and Cultural Heritage (INTACH) have one of the largest networks of heritage activists, artists, art historians, architects and amateur historians who have been intervening in educating both the young and the lay public about heritage through the Heritage Education and Communication Service which was established in 1998. INTACH has also been undertaking numerous conservation projects. Although INTACH has never been recognised by academia, it has contributed the largest number of student volunteers to work on heritage sites and has engaged with the historical interpretation of these sites. In 2012, INTACH set up the INTACH Heritage Academy, giving a formal structure to the work it had been doing in training, research and capacity building in field of heritage.

However, in recent years, there have been several attempts towards building sustainable public history engagements with recent history from within academic spaces. Many of these engagements have focused on community history and attempted to present the voices of those who had not been included in mainstream history until now. From 2013, the Centre for Community Knowledge (CCK) at the Ambedkar University in Delhi has created several neighbourhood museums, engaging with local history and local communities within the city. The neighbourhood museums are temporary displays that exhibit collected narratives from marginalised populations. Viewing 'documentation as an act of intervention', CCK raises questions about 'ascribed identities in the city'. ${ }^{3}$ They have created three such 'museums' to date - at Shadi Khampur, Nizamuddin and the Shadipur Shani Bazar. The 'museums' are set up for a month, sometimes longer, and use oral history, photographs and material from the community. The 'museum site', usually a gallery space, becomes a place for dialogue with the community and between disciplines. CCK has also been offering workshops on audio-visual documentation. The neighbourhood museums have been using the process itself as a pedagogic tool through which students can learn to collect and interpret diverse historical resources and curate them meaningfully.

The Centre for Public History (CPH), which began in 2011, is uniquely located within the Srishti Institute of Art, Design and Technology in Bangalore. The first centre of its kind in India, $\mathrm{CPH}$ attempts through its courses and projects to fill the lacuna that exists 
between historical research and its communication to a wider audience. Committed to the creation of resources for research, $\mathrm{CPH}$ has been involved in creating the archives of contemporary institutions. Deeply committed to dissemination of archives, $\mathrm{CPH}$ has developed the concept of the 'archival book' in which archival documents, photographs and oral history interviews are compiled and exhibited in ways that make them accessible to the general public. $\mathrm{CPH}$ has created archives and archival books for the Indian Institute of Management, Calcutta (2012), the Institute of Mathematical Sciences (2016) and the bicentenary commemoration volume for the Indian Museum (2017). The location of $\mathrm{CPH}$ within an institution of design has also created opportunities to work closely with designers and visual communicators, exploring different forms of interpretation that set up relationships between photographs, documents and oral narratives and in the process create new ways of doing history.

Connecting with audience experience, $\mathrm{CPH}$ has been exploring different forms of interpretation through the realm of performance and audio-visual communication. The Bangalore Storyscapes walks, lead at different points by Avehi Menon, Archit Guha, Priyanka Seshadri and Indira Bharadwaj, have used the city walk to engage with different aspects of Bangalore's layered history, deploying memory, archival documents and photographs. The Bangalore Fort project - 'The Tiger Comes to Town' - was a site-specific intervention that attempted to present a critical perspective of the past and re-engage local audiences with events from 1791 at the Bangalore Fort - a heritage site that is preserved and protected today by the Archaeological Survey of India. $\mathrm{CPH}$ anchors two masters programmes - in Public History and Heritage Interpretation and in Oral History. Both degrees are awarded by the University of Mysore. At the time of writing, there has been one student for oral history and none for public history, indicating that the discipline will take a while to find its academic roots in India.

\section{CONCLUSION}

For many decades in India there has been a practice around the public engagement with the past that has taken a variety of forms. And this appears to be growing throughout the country. Beginning in statefunded institutions such as museums, the practice seems to be slowly but surely emerging from the shadow of the state and its claim to be the sole representative of the public past. As part of this process, the conception of the public as a monolithic entity has been challenged, 
along with the belief that a singular interpretation of the past is sufficient for the public.

The acknowledgement of multiple publics in India has brought with it the recognition that each of these publics engage with a different past and, within themselves, even different versions of a shared past. As such, any effective engagement with the past must take into account the public whose past is being represented and make them stakeholders in the process of representation. That is what the Arna-Jharna, the Remember Bhopal Museum, the Partition Museum and the Virasat-eKhalsa have done.

What, however, has yet to happen in India is recognising this thriving practice of publicly engaging with the past as public history. The need for this may not be immediately apparent or even important, but recognition brings with it a formalisation of practice, a sharing of the practice through recognised platforms and the coming together of practitioners under a common banner. That might make it easier to attract funding for such projects - something that most public history projects struggle with - which in turn might create more opportunities for employment. An increase in employment opportunities might make the study of public history as a discipline and a practice more attractive for students who are interested in the past but do not necessarily want to become academic historians. And an increase in the number of welltrained professional public historians might mean more partnerships with many more communities who have not had their past represented, or represented in a manner that is meaningful to them.

If all these mights and maybes can be manifested, then the thriving practice of publicly engaging with the past could be transformed into a public history movement that unleashes the democratic potential inherent in public history and makes the past truly of the people, by the people and for the people.

\section{ENDNOTES}

We gratefully acknowledge the travel funding received from the Srishti Institute of Art, Design and Technology, Bangalore during our research-related site visits to museums and heritage sites in India. We particularly thank Dr. Geetha Narayanan, Founder-Director of Srishti for her generous support and encouragement.

'See Rustom Bharucha, Rajasthan, an Oral History: Conversations with Komal Kothari, Penguin, Delhi, 2003.

2 Available online: https:/ / www.youtube.com/watch?v=PteCQL6eUVY (accessed 7 September 2017).

${ }^{3}$ Dipesh Chakrabarty, 'The public life of history: an argument out of India', Postcolonial Studies, vol 11, no 2, 2008, p169. 
' Dipesh Chakrabarty, The Calling of History: Sir Jadunath Sarkar and His Empire of Truth, The University of Chicago Press, Chicago, 2015, p38.

'Chakrabarty, 'The public life of history', p170.

- ibid, p172.

ibid, p169.

'Centre for Historical Studies, Jawaharlal Nehru University, New Delhi, 'The

Political Abuse of History: The Babri Masjid-Rama Janmabhumi Dispute', Social Scientist, vol 18, no 1-2, 1990, pp76-81.

- Sarvepalli Gopal (ed), Anatomy of a Confrontation: The Rise of Communal Politics in India, Penguin, Delhi, 1991.

${ }^{10}$ Romila Thapar, 'The History Debate and School Textbooks in India: a Personal

Memoir', History Workshop Journal, vol 67, 2009, pp95-96.

"Romila Thapar, 'In defence of history', Seminar 521, 2003, http:/ / www.indiaseminar.com / 2003/521/521\%20romila\%20thapar.htm (accessed 7 September 2017).

${ }^{\prime}$ Badri Narayan, Women Heroes and Dalit Assertion in North India: Culture, Identity and Politics, Sage Publications, New Delhi, 2006, p89.

${ }^{13}$ ibid, p26.

${ }^{14}$ Kancha Ilaiah, 'Productive Labour, Consciousness and History: The Dalitbahujan

Alternative', in Shahid Amin and Dipesh Chakrabarty (eds), Subaltern Studies IX:

Writings on South Asian History and Society, Oxford University Press, New Delhi, 1996, pp165-200.

${ }_{15}$ See Gyan Prakash, 'Science “Gone Native" in Colonial India', Representations, vol 40, 1992, pp153-78 and Gyan Prakash, 'Museum Matters', in Bettina Messias Carbonell (ed), Museum Studies: An Anthology of Contexts, Wiley-Blackwell, Oxford, 2003, pp20816. See also Tapati Guha-Thakurta, Monuments, Objects, Histories: Institutions of Art in Colonial and Postcolonial India, Columbia University Press, New York, 2004.

${ }_{16}$ Centre for Public History and ARCH@Srishti, The Lives of Objects: Stories from the Indian Museum, Indian Museum, Kolkata, 2017, p139.

"Kavita Singh, 'The Museum is National', India International Centre Quarterly, vol 29, no 3-4, 2003, p192.

${ }_{18}$ ibid, p176.

19 Thomas Cauvin, Public History: A Textbook of Practice, Routledge, New York, 2016.

${ }^{20}$ Ronald J. Grele, 'Whose Public? Whose History? What Is the Goal of a Public

Historian?', The Public Historian, vol 3, no 1, 1981, p48.

${ }_{21}$ Kuldeep Kothari, interview by Indira Chowdhury, 31 March 2017.

"Available online: http:/ / www.arnajharna.org/English/Museum Concept.aspx (accessed 7 September 2017).

${ }^{23}$ Rustam Bharucha, interview with Amanda Fortier, The Power of Culture, http: / / kvc.minbuza.nl/en/current/2009/august/ desert-museum (accessed 7 September 2017).

${ }^{24}$ Amardeep Behl, conversation with Indira Chowdhury, April 6, 2017.

${ }^{25}$ Available online: http:/ / rememberbhopal.net/overview / (accessed 7 September 2017). For further details about the curation of the museum, see Rama Lakshmi, 'Curating a Bhopal People's Movement: An Opportunity for Indian Museums', The Museum Journal, vol 55, no 1, 2012, pp35-50.

${ }_{26}$ ibid.

${ }^{27}$ Available online: http:/ / spacematters.in/habitatresearch_initiatives.html (accessed 7 September 2017).

${ }_{28}$ Rama Lakshmi, email to Indira Chowdhury about the Bhopal disaster survivors' organisations' response to the International Coalition of Sites of Conscience about SpaceMatters and their proposed memorial, 10 May 2017.

${ }_{20}^{2}$ Lakshmi, 'Curating a Bhopal People's Movement', pp38-40.

${ }^{30}$ Available online: http:/ / rememberbhopal.net/overview / (accessed 7 September 2017).

${ }^{3}$ Urvashi Butalia, The Other Side of Silence: Voices from the Partition of India, Penguin Books, New Dehli, 1998, p3. 
${ }_{32}$ Adrian Murphy, 'Partition at 70: World's first Partition Museum officially opens in India', Museums+Heritage Advisor, 17 August 2017,

http:/ / advisor.museumsandheritage.com/ news / partition-70-worlds-first-partitionmuseum-officially-opens-india/.

${ }^{3}$ Paul Ashton and Alexander Trapeznik, 'The Public Turn: History Today', in Paul

Ashton and Alexander Trapeznik (eds), What is Public History Globally?, Bloomsbury, London and New York, forthcoming 2018).

${ }^{3}$ Available online: http:/ / www.cckonline.in/neighborhood-museumprogramme.html (accessed 7 September 2017). 